\title{
기술보문 《
}

\section{폐 커피 캡슐의 재활용을 위한 재질분리 공정 개발}

\author{
백상호* · 한요셉*** · 김성민* · Tsogchuluun Davaadorj** . 전호석**** \\ *한국지질자원연구원 광물자원연구본부 자원회수연구센터, **과학기술연합대학원대학교 자원순환공학과
}

\section{Development of Material Separation Process for Recycling Waste Coffee Capsules}

\author{
Sang-Ho Baek*, Yosep Han***, Seongmin Kim*, Tsogchuluun Davaadorj** and ${ }^{\S}$ Ho-Seok Jeon ${ }^{* * *}$ \\ *Resources Recovery Research Center, Mineral Resources Division, \\ Korea Institute of Geoscience and Mineral Resources \\ **Department of Resources Recycling, University of Science and Technology
}

\begin{abstract}
요 약
본 연구에서는 현재 생활계 폐기물로 폐기되는 커피 캡슐의 재질분리 공정 개발을 통해 폐플라스틱의 재활용 가능성을 평가하였다. 1 차 파쇄, 세척 및 체질을 통해 커피찌꺼기를 제거하고 2 차 파쇄 후, 총 3 번의 코로나 방전형 정전선별을 수행하는 재질분리 공정이 개발되 었다. 이때, $-10 \mathrm{~mm}$ 시료는 최적조건에서 알루미늄 제거율과 플라스틱 회수율이 각각 $95.4 \%$ 와 $98.3 \%$ 이었으며, $-15 \mathrm{~mm}$ 는 각각 $91.3 \%$ 와 $97.2 \%$ 이었다. 재질분리 된 폐플라스틱의 재활용 가능성을 평가하기 위하여, 시료를 펠릿으로 제조하고 물성을 분석하였다. 분석결과, 유해물질은 검출되지 않았으며, Homo-PP와 유사한 결과를 보였다. 따라서 재생 PP로 충분한 기능성이 존재하는 것을 확인하였다. 다만, 어두운 색상으로 인해 검정 혹은 어두운 계열의 제품군에 한정적으로 적용 가능할 것으로 평가되었다.
\end{abstract}

주제어 : 커피 캡슐, 재활용, 재질분리, 코로나 방전형 정전선별, 재생 플라스틱

\begin{abstract}
This study evaluated the recyclability of waste plastics in used coffee capsules disposed of as municipal waste. For recycling, a new material separation process was developed to remove the coffee grounds through primary crushing, washing, sieving, and secondary crushing, followed by corona discharge electrostatic separation. Furthermore, for the under $10 \mathrm{~mm}$ size fraction samples, the aluminum removal and the plastic recovery were $95.4 \%$ and $98.3 \%$, respectively, under optimal conditions. In addition, for the $15 \mathrm{~mm}$ fraction samples, the aluminum removal and the plastic recovery were $91.3 \%$ and $97.2 \%$, respectively. To evaluate the recyclability of the separated waste plastics, the samples were pelleted, and their material properties were analyzed. No hazardous substances were detected, and the results were similar to those for homo-PP. Therefore, it was confirmed that sufficient functionality existed as recycled PP. However, owing to the dark color of the pellets, limited applications to black or dark products are expected.
\end{abstract}

Key words : Coffee capsule, Recycling, Material separation, Corona discharge electrostatic separation, Recycled plastic

\footnotetext{
- Received : April 6, $2021 \cdot$ Revised : April 30, $2021 \cdot$ Accepted : May 3, 2021

${ }^{\S}$ Corresponding Author : Ho-Seok Jeon (E-mail : hsjeon@kigam.re.kr)

Mineral Resources Division, Korea Institute of Geoscience and Mineral Resources, 124 Gwahank-ro, Yuseong-gu, Daejeon 34132 , Korea

(c) The Korean Institute of Resources Recycling. All rights reserved. This is an open-access article distributed under the terms of the Creative Commons Attribution Non-Commercial License (http://creativecommons.org/licenses/by-nc/3.0/), which permits unrestricted non-commercial use, distribution and reproduction in any medium, provided the original work is properly cited.
} 


\section{1. 서 론}

플라스틱은 여러 가지 기능적 우수성과 저가라는 경제 상의 특징으로 사용량이 해마다 증가하고 있다. 국내 플 라스틱 원료 생산은 2011년 약 1,200만 톤에서 2015년 약 1,1415 만 톤으로 증가하였으며, 국내 수요 또한 약 495만 톤에서 약 583만 톤으로 증가하였다. Eromap에 따르면, 2015 년 기준 한국은 연간 약 $132.7 \mathrm{~kg} / \mathrm{capita}$ 의 플라스틱 을 소비하고 있으며, 이는 조사 대상인 63 개국 중 두 번째 로 많은 양이다 ${ }^{1)}$. 국내 플라스틱 제조 산업의 성장은 플라 스틱 폐기물의 증가로 나타나고 있으며, 2011년 506만 톤 에서 2017년 791만 톤으로 56\% 증가하였다. 이 중 생활 계 폐플라스틱의 발생량은 153 만 톤에서 213만 톤으로 $39 \%$ 증가하였다. 이는 1 인 가구의 증가에 따라 외식이나 가공식품을 구입하는 경향이 증가하고 인터넷 발달과 스 마트폰의 보급 장가에 따라 온라인 쇼핑의 이용이 급증한 것에 기인한다. 이러한 소비패턴의 변화로 제품의 포장 사용량 등이 증가하여 폐플라스틱의 발생량이 지속적으 로 증가하고 있다 ${ }^{2)}$

국내의 2017년 플라스틱 폐기물 재활용 처리량은 2011 년 대비 약 $85 \%$ 증가하여, 489 만 톤이 재활용되었으며, 나머지 242만 톤은 소각, 37만 톤은 매립되었다. 매년 플 라스틱 제품 소비량이 증가하면서 처리량도 늘어나는 추 세이다(Fig. 1). 이 중 산업계에서 스크랩 등으로 발생하 는 폐플라스틱은 조성이 일정해 재활용에 큰 어려움이 없 다. 그러나 생활계 폐플라스틱은 대개 여러 종류의 플라 스틱이 혼합되어 배출되고 계절 및 지역에 따라 조성이 일

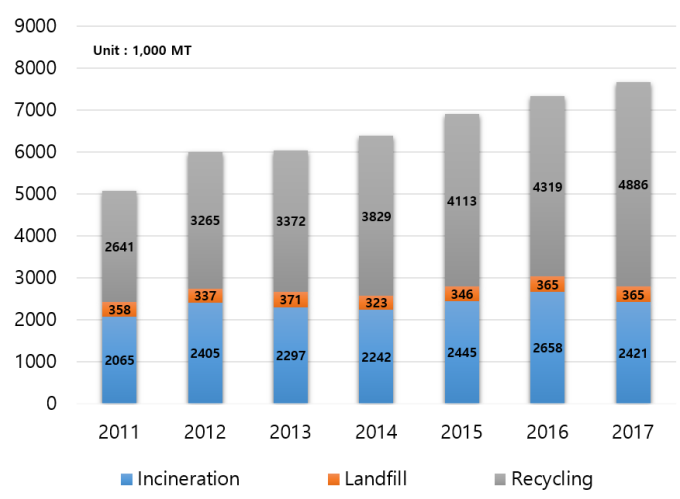

Fig. 1. Current status of domestic waste plastic treatment (2011-2017).
정하지 않아 재활용에 어려움을 겪고 있달. 소각하여 감 용화 하는 것이 가능한 고체 폐기물은 소각이나 매립이 일 반적이지만, 폐플라스틱의 소각이나 매립은 매립지의 부 족, 환경오염 문제 등을 야기하고 있다3).

국내외적으로 폐기물에 대한 재활용 요구, 정책의 시 행, 법적 규제로 수명이 다한 폐기물의 재자원화 요구가 증가하고 있다. 국내에서도 2018년 자원순환기본법을 시 행하여 소각 및 매립의 최소화를 통한 재활용 활성화와 극 대화를 추진하고 있어 폐기물의 재활용 기술개발이 필요 하다. 또한 세계 플라스틱 폐기물의 절반을 수입하던 중 국이 2017년 7월 '외국 쓰레기 반입 금지와 고형폐기물 수입, 관리 개혁 실시 방안’을 발표하여 세계 각국에서 폐 기물 처리에 어려움을 겪고 있다 ${ }^{4}$. 따라서 국내에서 발생 한 폐플라스틱은 국내에서 재활용 하는 것이 시급한 문제 로 대두되고 있다.

2016년 영국 BBC 뉴스에 따르면 해마다 커피 캡슐의 소비량은 증가하고 있으며, 이는 심각한 환경 문제를 동 반한다고 보고하고 있다. 일반 커피 머신에 비해 더 간단 하고 저렴하게 추출이 가능한 캡슐 커피 머신의 전 세계 판매량은 2010년과 2017년 사이 두 자릿수 정장을 기록 하였다(2022년 11.35억 달러, 2026년 18.84억 달러 예 상). 특히, 아시아 태평양 지역의 커피 소비 증가가 커피 캡 슐 시장 규모를 성장시키는 주요 요인으로 분석되었다 ${ }^{5}$. 국내의 시장 규모는 최근 5 년간 매년 $20 \%$ 씩 가파르게 성 장해 2020년 기준 머신 매출 787억 원, 캡슐 매출 1333억 원에 이르며, 코로나 19 사태 이후 소비량이 더욱 높아졌 다. 본 연구의 대상 시료인 플라스틱 커피 캡슐의 경우, 케 이스의 대부분 플라스틱으로 구성되어 있지만, 알루미늄 및 커피 찌꺼기(coffee grounds)로 인해 재활용에 어려움 을 겪고 있다. 현재 국내에서는 생활계 폐기물로 분류되 어 버려지고 있어, 자원의 효율적인 이용 및 환경문제 등 을 이유로 재활용이 요구되고 있다. 본 연구에서는 폐 커 피 캡슐의 재질분리 공정 개발을 통해 커피 캡슐 폐플라스 틱의 재활용 가능성을 평가하였다.

\section{2. 연구개발 수행내용 및 결과}

\section{1. 시료의 특성 및 실험방법}

Fig. 2는 본 연구에 사용된 NESCAFE Dolce Gusto (Nestle, Switzerland) 커피 캡슐의 구성을 나타낸 것으로, 


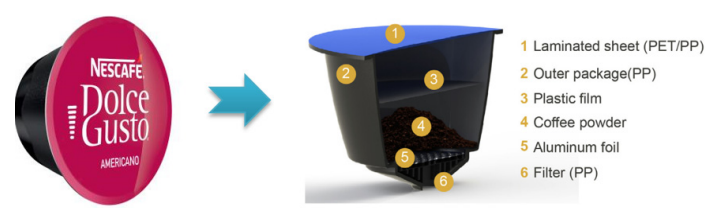

Fig. 2. Composition of coffee capsules used in this study.

Table 1. Weight ratio by material of coffee capsules used in this study

\begin{tabular}{|c|c|c|c|}
\hline Materials & Weight (g) & $\begin{array}{c}\text { Weight \% } \\
\text { (with coffee) }\end{array}$ & $\begin{array}{c}\text { Weight \% } \\
\text { (without } \\
\text { coffee) }\end{array}$ \\
\hline Aluminum & 0.0924 & 0.67 & 2.72 \\
\hline Plastic & 3.3087 & 24.68 & 97.28 \\
\hline Coffee & 10.0067 & 74.63 & - \\
\hline Total & 13.4078 & 100.00 & 100.00 \\
\hline
\end{tabular}

Table 2. Particle size distribution of coffee grounds

\begin{tabular}{|c|c|c|c|c|}
\hline $\begin{array}{c}\text { Mesh } \\
(\mathrm{mm})\end{array}$ & $\begin{array}{c}+12 \\
(+1.41)\end{array}$ & $\begin{array}{c}-12 /+18 \\
(-1.41 /+1.00)\end{array}$ & $\begin{array}{c}-18 /+35 \\
(-1.00 /+0.42)\end{array}$ & $\begin{array}{c}-35 \\
(-0.42)\end{array}$ \\
\hline Wt. \% & 0.03 & 0.98 & 65.59 & 16.02 \\
\hline
\end{tabular}

캡슐을 밀봉하는 라미네이트 시트\{PET (polyethylene terephthalate)/PP (polypropylene)\}, 외부 용기(PP), 플라스틱 필름(PP), 커피 분말, 알루미늄 호일, 플라스틱 필터(PP) 로 구성되어 있닿. 알루미늄 호일의 경우, 플라스틱과 점 착되어 있어 재질분리를 위해서는 플라스틱과 알루미늄 호일의 단체분리가 필요할 것으로 생각된다. 또한 알루미 늄 호일을 제외한 플라스틱의 대부분이 PP 재질로 플라스 틱과 알루미늄이 분리된다면 재활용이 가능할 것으로 판 단된다. Table 1 은 본 연구에 사용된 커피 캡슐의 재질별 무게 비를 나타낸 것으로, $74.63 \%$ 가 커피이며, 그 외 플라 스틱이 $24.68 \%$ 그리고 알루미늄이 $0.67 \%$ 임을 확인하였 다. 커피를 제외한 무게 비는 플라스틱이 $97.28 \%$ 로 대부 분이며, 알루미늄은 $2.72 \%$ 이었다.

Table 2는 본 연구에 사용된 커피 캡슐의 커피 찌꺼기 에 대한 입도분석(particle size analysis) 결과를 나타낸 것으로, 대부분이 $-18 /+35$ mesh $(-1.00 /+0.42 \mathrm{~mm})$ 입도 에 분포하고 있는 것을 확인할 수 있다. 또한 $12 \mathrm{mesh}$ $(1.41 \mathrm{~mm})$ 보다 큰 커피 찌꺼기는 $0.03 \%$ 로 미미하여 대 부분 $12 \mathrm{mesh}$ 이하임을 알 수 있다. 따라서 커피 찌꺼기의 완전한 제거를 위해서는 12 mesh 이상의 체(screen)를 이 용하여야 함을 확인하였다.
본 연구에서는 미립자 발생을 억제하여 체를 통과하는 플라스틱과 알루미늄을 최소화하기 위해 파쇄를 2단계로 진행하였다. 먼저, 시료를 슈레더(shredder) cutter의 회전 속도 $30 \mathrm{rpm}$ 조건에서 1차 파쇄하고 파쇄 된 시료를 세척 한 후, 체질(screening)하여 커피찌꺼기를 제거하였다. 이 때, 체를 통과한 산물은 여과하고 건조하였으며, 체에 남 은 산물은 건조한 후, $600 \mathrm{rpm}$ 의 고속파쇄기인 컷 크러셔 (cut crusher)를 이용하여 2차 파쇄하였다. 일정한 크기 $(-10,-15,-20 \mathrm{~mm}) 2$ 차 파쇄 된 시료는 코로나 방전형 정전선별(corona charged electrostatic separation)을 이 용하여 전도성 산물(알루미늄)과 비전도성 산물(플라스 틱)로 분리하였다.

\section{2. 알루미늄과 플라스틱의 재질분리}

\subsubsection{1차 파쇄 및 커피찌꺼기 제거}

폐 커피 캡슐의 재활용을 위해서는 커피찌꺼기의 제거 가 선행되어야 한다. 먼저 폐 커피 캡슐을 슈레더를 이용 하여 1차 파쇄하고 커피찌꺼기 탈리를 위해 일정시간(2분) 물과 교반하며 세척한 후, 체질하여 커피찌꺼기를 제거하 였다. 커피찌꺼기의 입도분석 결과, $99.97 \%$ 가 $12 \mathrm{mesh}$ 이 하임을 확인하였다. 따라서 본 연구에서는 커피찌꺼기의 완전한 제거를 위해 $8 \mathrm{mesh}(2.38 \mathrm{~mm})$ 체를 이용하여 커 피 찌꺼기를 제거하였다. 체질을 통해 커피찌꺼기가 제거 되고 남은 산물은 건조하였으며, 플라스틱과 알루미늄이 $99.9 \%$ 이상임을 확인하였다.

1 차 파쇄 되고 커피찌꺼기가 제거된 시료의 알루미늄 단체분리도(degree of liberation) 확인을 위하여 단체분 리 된 플라스틱과 알루미늄 그리고 단체분리 되지 않은 시 료로 수작업을 통해 분류하였다(Fig. 3). 확인 결과, 1차 파쇄 후 시료의 알루미늄 단체분리도는 $50.8 \%$ 이었다. 따 라서 플라스틱과 알루미늄의 재질분리를 위해서는 2차 파쇄를 통한 단체분리도 향상이 필요하다는 것을 확인하 였다.

\subsubsection{2차 파쇄}

1 차 파쇄 된 시료의 알루미늄 단체분리도는 $50.8 \%$ 이 었다. 따라서 알루미늄 단체분리도 향상을 위해 컷 크러 셔를 이용하여 $10,15,20 \mathrm{~mm}$ 이하로 2차 파쇄를 수행하 였다. 파쇄 된 시료는 알루미늄 단체분리도 확인을 위하 여 단체분리 된 플라스틱과 알루미늄 그리고 단체분리 되 


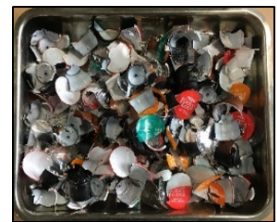

$1^{\text {st }}$ crushed sample

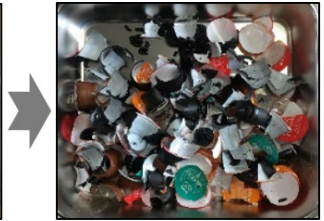

Plastic

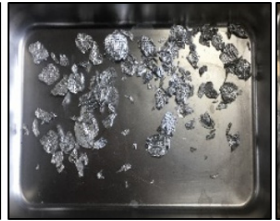

Aluminum

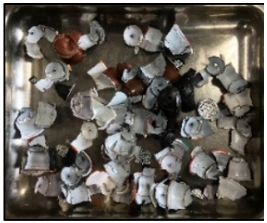

Non-liberated product

Fig. 3. Classification of the first crushed samples.
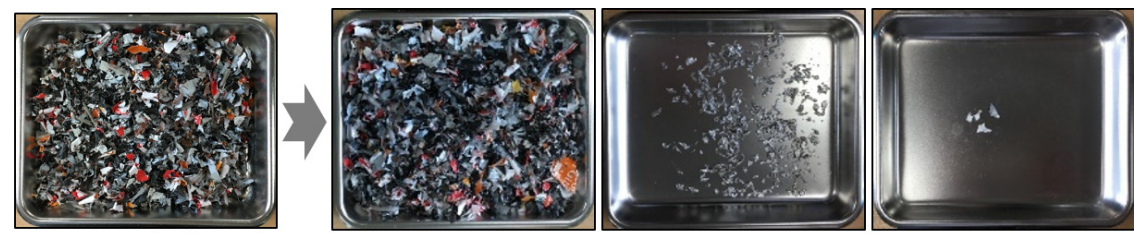

$-10 \mathrm{~mm}$ crushed sample

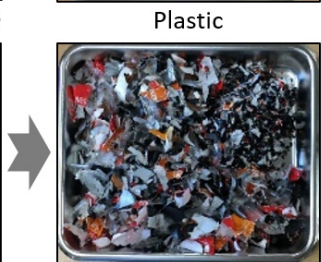

Aluminum

Non-liberated

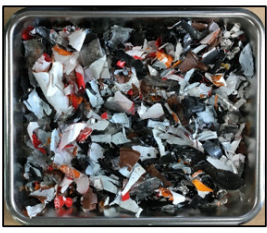

$-15 \mathrm{~mm}$ crushed sample

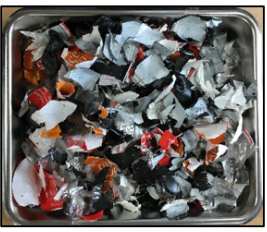

$-20 \mathrm{~mm}$ crushed sample

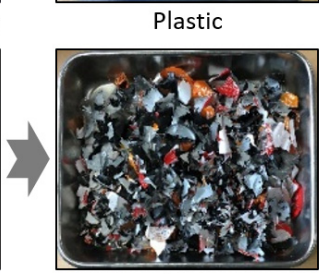

Plastic

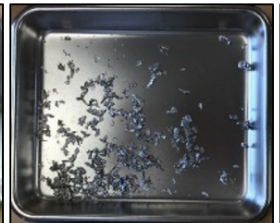

Aluminum

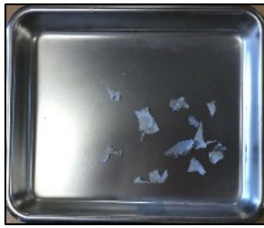

Non-liberated

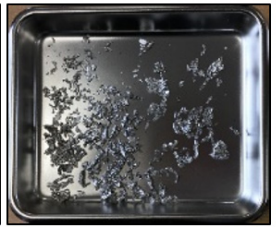

Aluminum

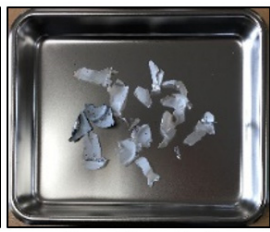

Non-liberated

Fig. 4. Classification of secondary crushed samples $(-10,15,20 \mathrm{~mm})$.

지 않은 시료로 수작업을 통해 분류하였다. Fig. 4는 10, $15,20 \mathrm{~mm}$ 이하로 파쇄 된 시료의 분류 산물을 나타낸 것 이다. $-10 \mathrm{~mm}$ 로 파쇄 된 시료의 경우, 알루미늄 단체분리 도는 $99.2 \%$ 로 매우 높았으며, -15 와 $-20 \mathrm{~mm}$ 시료는 각 각 $97.1 \%$ 와 $95.5 \%$ 이었다. 파쇄 입도가 작아질수록 알루 미늄의 단체분리도는 증가하였으며, 세 시료 모두 알루미 늄 단체분리도가 $95 \%$ 이상으로 플라스틱과 알루미늄의 단체분리가 효과적으로 이루어졌음을 확인하였다.

\subsection{3. 코로나 방전형 정전선별}

본 연구에서는 $-10,15,20 \mathrm{~mm}$ 로 2 파 파쇄 된 시료를 대상으로 코로나 방전형 정전선별을 이용하여 전도성 산 물(알루미늄)과 비전도성 산물(플라스틱)로 재질분리 연 구를 수행하였다. Fig. 5 는 코로나 방전형 정전선별의 원 리 및 장치를 나타낸 것으로, 코로나 전극에 음극의 직류
고전압을 발생시키면 주변 공기는 전기적 절연파괴를 일 으키고, 방전하게 되어 도체의 성질을 지니게 된다. 이 현 상을 이온 충격(ion bombardment)이라 하며, 방전된 기 체들은 정전기장을 형성한다. 선별기에 투입된 입자들은 정전기장을 통과하며 하전이 일어나지만, 접지된 회전 전극으로 인해 전하를 잃게 된다. 이때 금속입자는 전도 성이 커서 전하소멸이 빠르게 일어나 회전 전극으로부터 궤적을 그리며 낙하하게 된다. 반면 비금속 입자는 전도 성이 작아 전하소멸이 천천히 일어나 거울상 힘(image force)에 의해 회전 전극에 부착되어 돌다 브러시에 의해 드럼에 떨어져 선별이 이루어진다. 코로나 방전형 정전선 별에 영향을 주는 변수는 다양하다. 입자 변수로 입도, 밀 도, 형상, 유전율 등이 있으며, 선별기에서 제어하는 공정 변수로는 시료의 공급량, 회전 드럼의 속도, 적용 전압, 코 로나 및 유도 전극에서 드럼까지의 거리, 분리대의 위치 

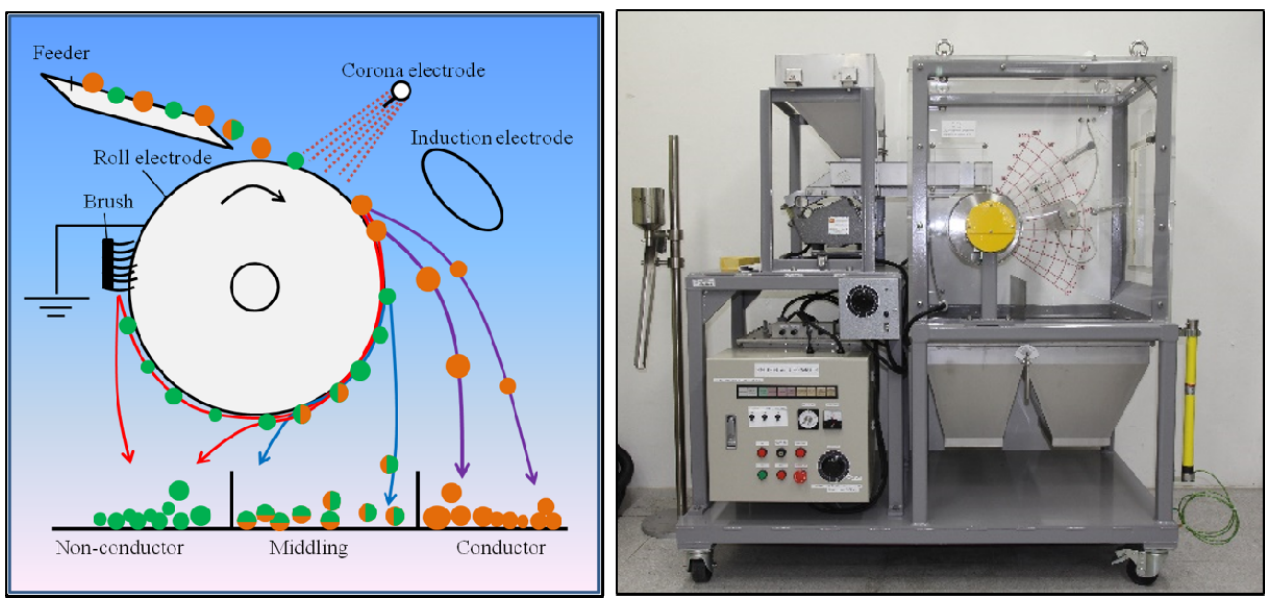

Fig. 5. Principle \& equipment of corona charged electrostatic separation.

등이 있다. 또한 상대습도, 온도 등의 환경적이 변수가 있 다 ${ }^{7-9)}$. 본 연구에서는 시료의 공급량 $(300 \mathrm{~g} / \mathrm{min}$.), 코로나 및 유도 전극에서 드럼까지의 거리 $(20 \mathrm{~cm})$, 상대습도(45 $50 \%)$ 그리고 온도 $\left(25 \sim 30{ }^{\circ} \mathrm{C}\right)$ 조건은 고정되었으며, 입 도, 드럼의 회전 속도, 적용 전압, 분리대의 위치 그리고 정선 횟수를 변화하며 최적 분리조건 및 분리효율을 확인 하였다.

본 연구에서 코로나 방전형 정전선별의 목적은 알루미 늄의 제거는 최대한으로 그리고 플라스틱은 가급적 많이 회수하는 것이다. 따라서 선별효율은 비전도성 물질 회수 대로 회수된 산물의 알루미늄 제거율과 플라스틱 회수율 을 기반으로 평가되었다. 알루미늄 제거율과 플라스틱 회 수율은 아래와 같이 계산되었다.

$$
\begin{aligned}
& A l_{\text {rem }}=\frac{T_{a}}{C_{a}+T_{a}} \times 100 \\
& P_{\text {rec }}=\frac{C_{p}}{C_{p}+T_{p}} \times 100
\end{aligned}
$$

여기에서 Alrem은 알루미늄 제거율, $\mathrm{Ca}$ 는 비전도성 물질 회수대의 알루미늄 함량, $\mathrm{Ta}$ 는 전도성 물질 회수대의 알 루미늄 함량이다. 그리고 $\mathrm{Prec}$ 는 플라스틱 회수율, $\mathrm{Cp}$ 는 비전도성 물질 회수대의 플라스틱 함량, $\mathrm{Tp}$ 는 전도성 물 질 회수대의 플라스틱 함량이다.
(1) $-10 \mathrm{~mm}$ 시료

Fig. 6의 A는 전압세기가 선별효율에 미치는 영향을 관찰하기 위하여 드럼의 회전 속도 $60 \mathrm{rpm}$, 분리대의 위 치 $20^{\circ}$ 로 고정하고 코로나 및 유도 전극에 적용되는 전압 을 $-20 \mathrm{kV}$ 에서 $-40 \mathrm{kV}$ 까지 변화하며 실험한 결과이다. 실험결과, 전압세기가 증가할수록 알루미늄 제거율과 플 라스틱 회수율이 증가하지만, $-30 \mathrm{kV}$ 이상에서는 큰 변 화가 없는 것을 알 수 있다. 즉, 즉, 전압세기가 가장 약한 $-20 \mathrm{kV}$ 에서는 알루미늄 제거율과 플라스틱 회수율이 각 각 $71.7 \%$ 와 $82.2 \%$ 로 가장 낮지만, $-40 \mathrm{kV}$ 에서는 각각 $79.2 \%$ 와 $99.7 \%$ 까지 증가하였다. 그러나 $-30 \mathrm{kV}$ 에서도 각각 $79.7 \%$ 와 $99.4 \%$ 로 높은 선별효율을 보였다. 따라서 선별효율을 높이기 위해서는 $-30 \mathrm{kV}$ 이상의 고전압을 공 급해야 함을 확인하였다. 이와 같이 전압세기가 선별효율 에 영향을 미친 이유는, 고전압은 더 강한 전기장을 생성 하고 전기장의 분포를 보다 광범위하고 균일하게 만들고, 강한 유도 전극의 영향으로 전도성 산물이 강하게 편향되 기 때문이다. 또한 코로나 방전형 정전선별에서 적용 전 압은 전도성 산물보다 비전도성 산물에 더 영향을 미치며, 이는 전압의 세기가 비전도성 산물을 드럼에 부착시키는 거울상 힘에 많은 영향을 주기 때문이다 ${ }^{8)}$.

드럼의 회전 속도는 빠를수록 전도성 산물이 원심력을 더 받아 드럼으로부터 멀리 편향되어 선별효율이 증가할 것 같지만, 회전 속도가 빠르면 정전기력과 거울상 힘보 다 원심력이 커져 비전도성 산물이 드럼에 오래 부착하지 못하고 빠르게 탈착된다. 따라서 비 전도성 산물이 드럼 

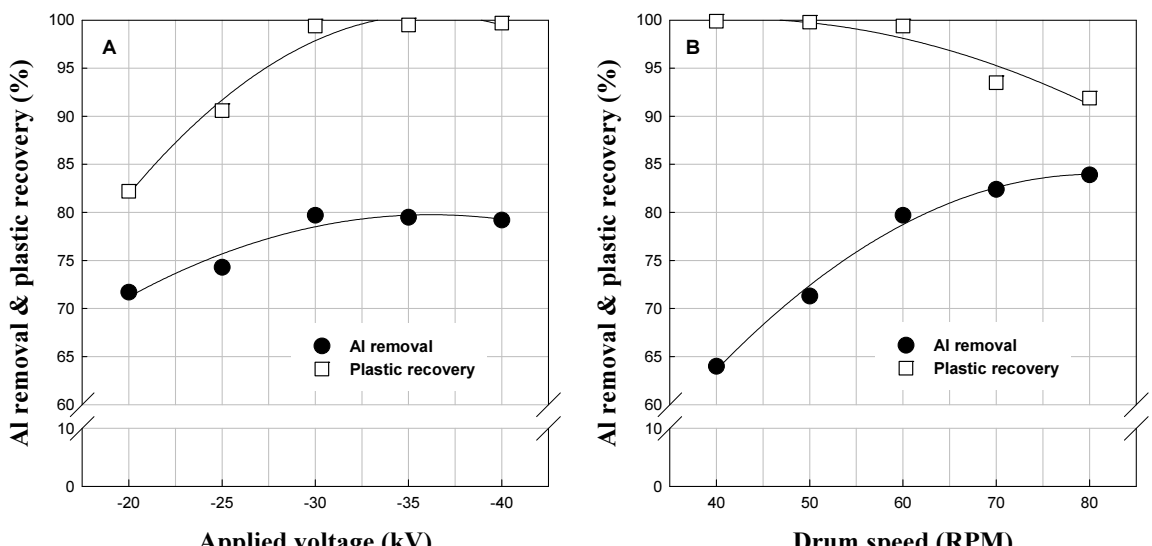

Applied voltage (kV)

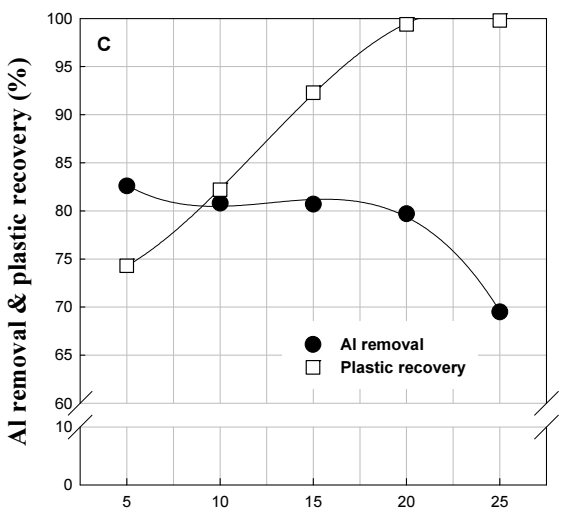

Splitter position (angle)

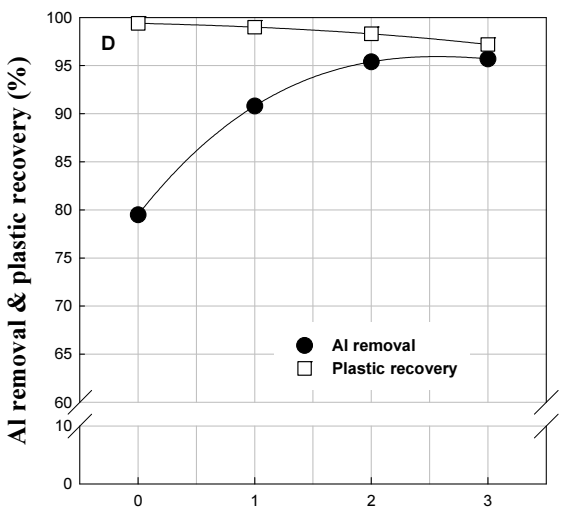

Cleaning times

Fig. 6. Effect of various factors in corona discharged electrostatic separation $(-10 \mathrm{~mm})$.

에 오래 부착되고 전도성 산물이 드럼으로부터 멀리 편향 될 수 있는 최적의 속도를 찾아야 한다. Fig. 6의 B는 드럼 의 회전 속도가 선별에 미치는 영향을 관찰하기 위하여 전 압 세기 $30 \mathrm{kV}$, 분리대의 위치 $20^{\circ}$ 로 고정하고 드럼의 회 전 속도를 $40 \mathrm{rpm}$ 에서 $80 \mathrm{rpm}$ 까지 변화하며 실험한 결과 이다. 실험결과, 드럼의 회전 속도가 증가할수록 알루미 늄 제거율은 증가하지만 플라스틱 회수율은 감소하는 것 을 알 수 있다. 즉, 회전 속도가 가장 느린 $40 \mathrm{rpm}$ 에서 알 루미늄 제거율은 $64.0 \%$ 이지만, 가장 빠른 $80 \mathrm{rpm}$ 에서는 $83.9 \%$ 까지 증가한다. 반면 플라스틱 회수율의 경우, 40 $\mathrm{rpm}$ 에서 $99.9 \%$ 로 가장 높지만 $80 \mathrm{rpm}$ 에서는 $91.9 \%$ 까지 감소한 것을 확인할 수 있다. 본 연구에서는 플라스틱 회 수율이 크게 감소하지 않고 알루미늄 제거율이 크게 증가 한 $60 \mathrm{rpm}$ 을 최적 조건으로 재질분리 실험을 수행하였다. 선별부 내에서 하전 된 입자의 하전량, 무게, 형태 등이
다르기 때문에 드럼에서 편향되는 거리 및 드럼에 부착되 는 시간이 다르다 ${ }^{10)}$. 따라서 선별부 하단에 위치한 분리대 를 이동시켜 선별에 적합한 조건을 얻을 수 있다. Fig. 6의 $\mathrm{C}$ 는 분리대의 위치가 선별에 미치는 영향을 관찰하기 위 하여 전압 세기 $30 \mathrm{kV}$, 드럼의 회전 속도 $60 \mathrm{rpm}$ 으로 고 정하고 분리대의 위치를 $5^{\circ}$ 에서 $25^{\circ}$ 까지 변화하며 실험 한 결과이다. 실험 결과, 분리대의 각도가 커질수록 알루 미늄 제거율은 감소하나 플라스틱 회수율은 증가하는 것 을 알 수 있다. 반대로 분리대의 각도가 작아질수록 알루 미늄 제거율은 증가하나 플라스틱 회수율이 감소하는 것 을 확인하였다. 본 연구에서 분리대의 위치는 알루미늄 제거율이 크게 감소하지 않으면서 플라스틱 회수율이 크 게 증가한 $20^{\circ}$ 를 최적 분리대 위치로 선택하였다. 이때 알루미늄의 제거율과 플라스틱 회수율이 각각 $79.7 \%$ 와 $99.4 \%$ 인 결과를 얻었다. 이와 같이 분리대의 위치에 따라 


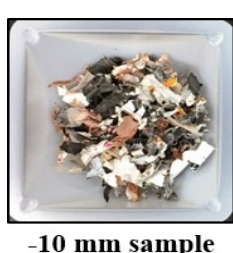

$-10 \mathrm{~mm}$ sample

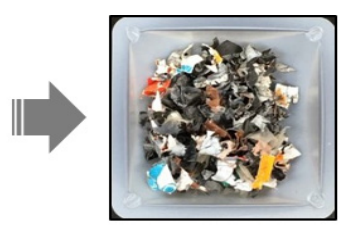

Conduct

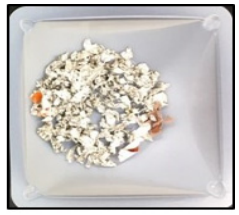

Non-conduct

Fig. 7. Products obtained in corona discharge electrostatic separation $(-10 \mathrm{~mm})$.

선별효율이 달라지는 이유는 회수존의 크기가 달라져 하 전량, 무게, 형태 등이 다른 전도성 및 비전도성 산물의 회 수량이 달라지기 때문이다.

본 연구에 사용된 시료의 경우, 과립(granule) 형태가 아니라 시료가 구겨지며 얇은 필름 또한 포함하고 있다. 그러므로 시료가 선별부로 투입될 때, 단일층(one layer) 으로 투입되기 어려워 알루미늄 제거율 향상에 한계가 있 다. 따라서 1 차로 회수된 비전도성 산물을 대상으로 알루 미늄 제거율 향상을 위한 정선(cleaning) 연구를 수행하였 다. Fig. 6 의 $\mathrm{D}$ 는 정선 횟수가 선별에 미치는 영향을 관찰 하기 위하여 0 회부터 3 회까지 실험한 결과이다. 실험결 과, 정선횟수가 늘어날수록 알루미늄 제거율이 증가하였 다. 즉, 0 회 일 때, $79.5 \%$ 에서 1 회와 2 회일 때, 각각 $90.8 \%$ 와 $95.4 \%$ 로 크게 증가하였다. 그러나 이보다 정선 횟수가 늘어난 3 회에서는 알루미늄 제거율의 뚜렷한 증가 없이 플라스틱 회수율만 감소하였다. 따라서 알루미늄 제거율 이 크게 증가하고 플라스틱 회수율이 크게 감소하지 않은 정선 횟수 2 회가 최적 조건임을 확인하였다.

Fig. 7은 $-10 \mathrm{~mm}$ 로 2차 파쇄 된 시료의 코로나 방전형 정전선별을 통해 회수된 산물을 나타낸 것으로, 육안으로 도 알루미늄이 효과적으로 제거된 것을 확인할 수 있다. $-10 \mathrm{~mm}$ 시료를 대상으로 한 코로나 방전형 정전선별에 서 최종적으로 회수된 산물의 알루미늄 제거율과 플라스 틱 회수율은 각각 $95.4 \%$ 와 $98.3 \%$ 이었다.

(2) $-15 \mathrm{~mm}$ 시료

Fig. 8 은 $-15 \mathrm{~mm}$ 로 2차 파쇄 된 시료를 대상으로 한 코 로나 방전형 정전선별 실험결과를 나타낸 것이다. 실험결 과는 $-10 \mathrm{~mm}$ 시료와 유사하였으며, 전압의 세기 $30 \mathrm{kV}$, 드럼의 회전 속도 $60 \mathrm{rpm}$, 분리대의 위치 $25^{\circ}$, 정선 횟수 2 회에서 최적의 결과를 얻었다. 이때 최종적으로 회수된 산 물의 알루미늄 제거율과 플라스틱 회수율은 각각 $91.3 \%$ 와 $97.2 \%$ 이었다. $-10 \mathrm{~mm}$ 시료와 비교하여 알루미늄 제
거율은 약 $4 \%$, 플라스틱 회수율은 약 $1 \%$ 적은 수치이며, 이는 알루미늄 단체분리도 및 입자의 하전량, 무게, 형태 등이 다르기 때문으로 판단된다. 선별효율은 $-10 \mathrm{~mm}$ 가 $-15 \mathrm{~mm}$ 보다 높지만, 파쇄 측면에서는 입도가 큰 -15 $\mathrm{mm}$ 가 효율적이다. 따라서 향후 입도는 선별효율 및 파쇄 효율을 고려해서 선택해야 할 것으로 생각된다. Fig. 9는 코로나 방전형 정전선별을 통해 최종적으로 회수된 산물 을 나타낸 것으로, $-10 \mathrm{~mm}$ 와 마찬가지로 육안으로도 알 루미늄이 효과적으로 제거된 것을 확인할 수 있다.

(3) $-20 \mathrm{~mm}$ 시료

Fig. 10 은 $-20 \mathrm{~mm}$ 로 2차 파쇄 된 시료를 대상으로 한 코로나 방전형 정전선별 실험결과를 나타낸 것이다. 실험 결과, 최적조건인 전압의 세기 $30 \mathrm{kV}$, 드럼의 회전 속도 $70 \mathrm{rpm}$, 분리대의 위치 $25^{\circ}$ 의 조건에서 알루미늄 제거율 과 플라스틱 회수율이 각각 $65.9 \%$ 와 $99.0 \%$ 이었다. 이는 $-10 \mathrm{~mm}$ 및 $-15 \mathrm{~mm}$ 시료와 비교하여 알루미늄 제거율이 $10 \sim 15 \%$ 낮은 결과이다. 따라서 본 연구에서 $-20 \mathrm{~mm}$ 시 료는 비효율적이라 판단하였으며, 입도는 $15 \mathrm{~mm}$ 이하가 되어야 함을 확인하였다.

\section{3. 플라스틱의 재활용}

폐플라스틱을 재생 플라스틱으로 제조하는 공정의 가 장 큰 어려움은 여러 종류로 혼재 된 폐플라스틱의 재질분 리이다. 혼합 폐플라스틱이 재질별로 분리되지 않으면, 물성 차이로 인해 재활용은 불가능하다 ${ }^{11)}$. 본 연구에 사용 된 시료의 경우, PP 재질이 대부분으로 알루미늄의 제거 만 효율적이라면 재생 플라스틱 제조에 큰 어려움이 없을 것으로 판단된다.

Fig. 11은 코로나 방전형 정전선별에 의해 회수된 커피 캡슐 폐플라스틱의 재생 플라스틱 제조가능성을 평가하 기 위한 펠릿화(pelletizing) 과정을 나타낸 것이다. 먼저 시료에 적합한 조건을 부여하고 시료를 공급한다. 공급된 

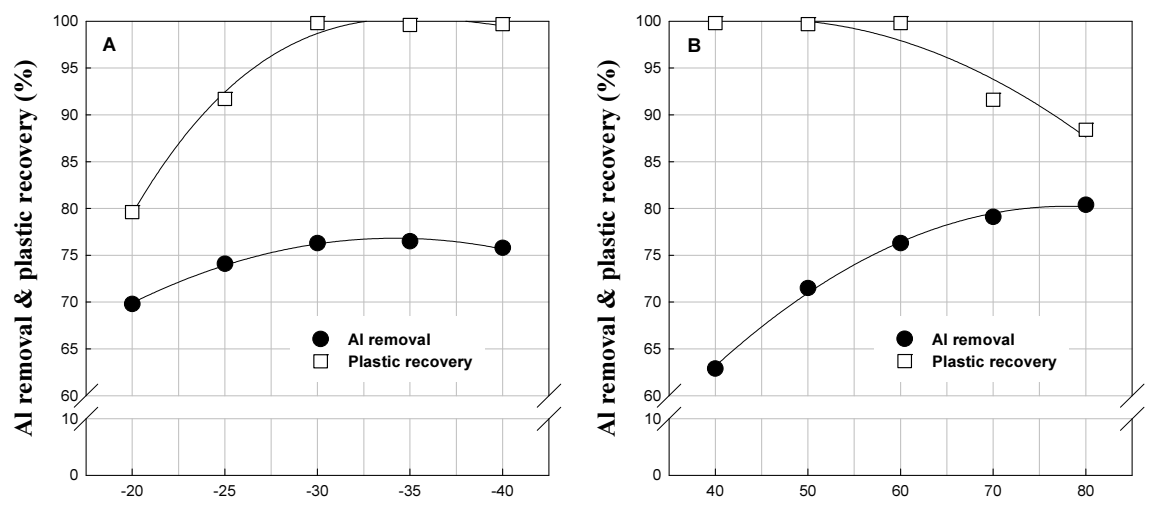

Applied voltage (kV)
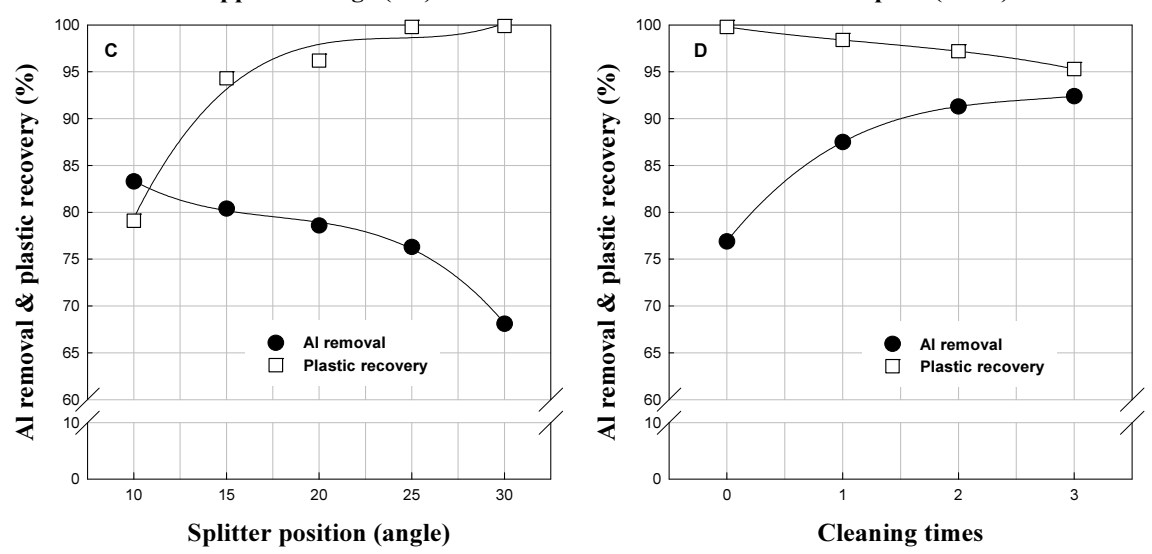

Fig. 8. Effect of various factors in corona discharged electrostatic separation $(-15 \mathrm{~mm})$.

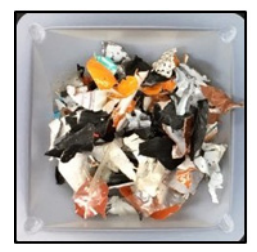

$-15 \mathrm{~mm}$ sample

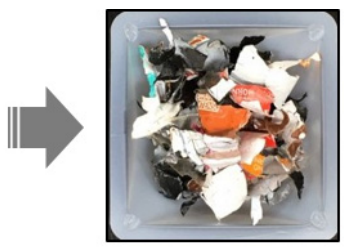

Conduct

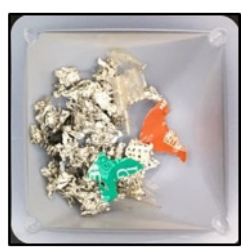

Non-conduct

Fig. 9. Products obtained in corona discharge electrostatic separation $(-15 \mathrm{~mm})$.

시료는 용융 과정을 거쳐 원통 모양으로 압출하여 성형시 킨다. 성형된 시료는 냉각수로 냉각하고 건조 과정을 거 친 후, 절단하여 펠릿으로 제조하였다. 펠릿화는 경기도 화성의 $\mathrm{D}$ 사에서 진행하였으며, 물성평가를 통해 재활용 가능성을 확인하였다.

Table 3 은 재생 플라스틱의 물성평가 결과를 나타낸 것 으로, 유해물질은 검출되지 않았으며, Homo-PP와 유사한 결과를 보였다. 미량의 불순물로 인해 다소 압축강도나 휨
강도가 낮은 편이나 대체적으로 GS 칼텍스의 Grade name $\mathrm{H} 550$ 과 유사한 기계적 물성을 갖는 것으로 확인되었다. Grade name $\mathrm{H} 550$ 의 경우, 시장에서 일반적으로 세탁기, 냉장고 등 가전제품, 식품 보관통, PP compound의 base 등으로 많이 사용되는 사용범위가 광범위한 수지이다. 따 라서 재생 PP로 충분한 기능성이 존재하며, 가전, 건축 등 의 일반적인 사출 소재로 사용이 가능할 것으로 판단된다. 또한 신재와 혼합사용 시, 등급이 높은 다양한 제품군에 

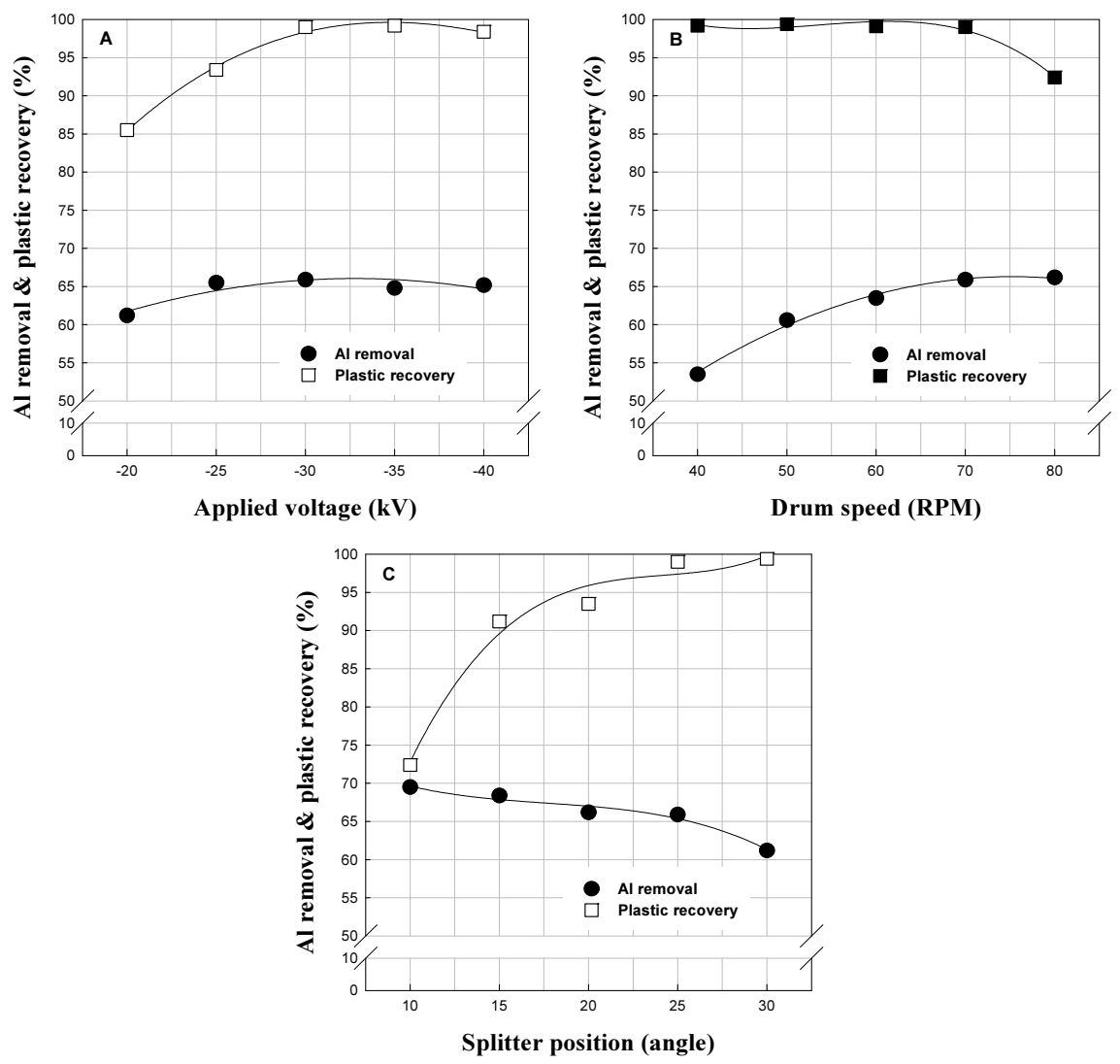

Fig. 10. Effect of various factors in corona discharged electrostatic separation $(-20 \mathrm{~mm})$.

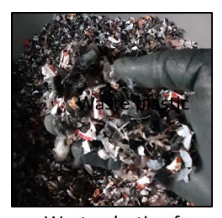

Waste plastic of coffee capsule

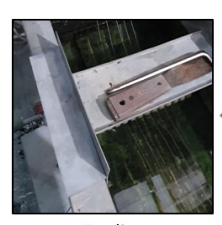

Cooling
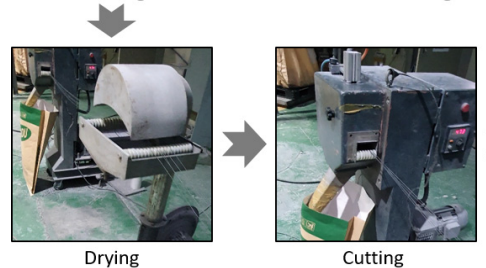

Cutting

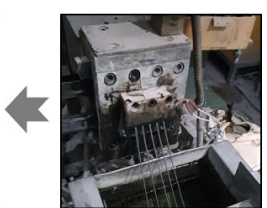

Extrusion molding

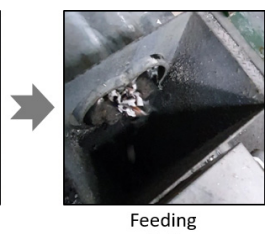

eeding

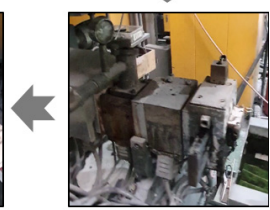

Melting

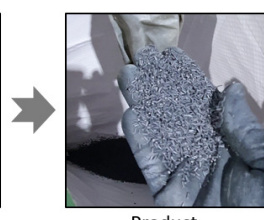

Product

Fig. 11. Pelletizing process of coffee capsule waste plastic. 
Table 3. Properties of the produced pellets and comparison with Grade name H550

\begin{tabular}{|c|c|c|c|c|}
\hline Item & Test methods & Unit & $\begin{array}{c}\text { Produced } \\
\text { samples }\end{array}$ & H550 \\
\hline $\begin{array}{l}\text { Specific } \\
\text { gravity }\end{array}$ & ASTM D-792 & $\mathrm{g} / \mathrm{cm}^{3}$ & 0.945 & 0.905 \\
\hline Flow index & $\begin{array}{l}\text { ASTM D-1238 } \\
\left(230^{\circ} \mathrm{C} / 2.16 \mathrm{~kg}\right)\end{array}$ & $\begin{array}{c}\mathrm{g} / \\
10 \mathrm{~min}\end{array}$ & 7.7 & 11.0 \\
\hline $\begin{array}{l}\text { Tensile } \\
\text { strength }\end{array}$ & ASTM D-638 & $\begin{array}{l}\mathrm{kgf} / \\
\mathrm{cm}^{2}\end{array}$ & 276 & 375 \\
\hline $\begin{array}{l}\text { Tensile } \\
\text { elongation }\end{array}$ & ASTM D-638 & $\%$ & 45 & 27 \\
\hline $\begin{array}{l}\text { Bending } \\
\text { strength }\end{array}$ & ASTM D-790 & $\begin{array}{l}\mathrm{kgf} / \\
\mathrm{cm}^{2}\end{array}$ & 365 & 423 \\
\hline $\begin{array}{l}\text { Bending } \\
\text { elasticity }\end{array}$ & ASTM D-790 & $\begin{array}{l}\mathrm{kgf} / \\
\mathrm{cm}^{2}\end{array}$ & 13.396 & $\begin{array}{c}15.03 \\
0\end{array}$ \\
\hline \multirow{2}{*}{$\begin{array}{l}\text { Impact } \\
\text { strength }\end{array}$} & ASTM D-256 (1/4") & $\begin{array}{c}\mathrm{kgfcm} / \\
\mathrm{cm}\end{array}$ & 4.2 & 3.2 \\
\hline & ASTM D-256 (1/8") & $\begin{array}{c}\mathrm{kgfcm} / \\
\mathrm{cm}\end{array}$ & 4.8 & 2.3 \\
\hline $\begin{array}{c}\text { Mineral } \\
\text { concentration }\end{array}$ & Combustion test & $\%$ & 1.7 & 0.0 \\
\hline $\begin{array}{l}\text { Contents of } \\
\text { hazardous } \\
\text { Substances }\end{array}$ & XRF & ppm & $\begin{array}{l}\mathrm{Br}: \mathrm{ND} \\
\mathrm{Pb}: \mathrm{ND} \\
\mathrm{Cr}: \mathrm{ND} \\
\mathrm{Hg}: \mathrm{ND} \\
\mathrm{Cd}: \mathrm{ND}\end{array}$ & \\
\hline
\end{tabular}

적용이 가능할 것으로 판단된다. 다만, 제조된 재생 펠릿 의 색상이 진회색으로 검정 혹은 어두운 계열의 제품군에 한정적으로 적용 가능할 것으로 생각된다.

\section{4. 폐 커피 캡슐 재질분리 공정}

본 연구에서는 폐 커피 캡슐의 재질분리 공정 개발을 통해 커피 캡슐 폐플라스틱의 재활용 가능성을 평가하였 다. Fig. 12는 본 연구에서 개발된 폐 커피 캡슐의 재질분 리 공정을 나타낸 것으로, 먼저 폐 커피 캡슐을 슈레더를 이용하여 1차 파쇄하고 파쇄 된 시료를 세척하였다. 세척 된 시료는 $8 \mathrm{mesh}$ 체를 이용하여 커피찌꺼기를 제거하였 으며, 이때 체를 통과한 산물(커피찌꺼기)은 여과하고 건 조하고 체에 남은 산물(플라스틱, 알루미늄)은 건조한 후, 컷 크러셔를 이용하여 2 차 파쇄 하였다. 2 차 파쇄에 의해 일정한 크기 $(-10$ 또는 $-15 \mathrm{~mm})$ 로 파쇄 된 시료는 1차 코 로나 방전형 정전선별에 의해 전도성 산물(알루미늄)과 비 전도성 산물(플라스틱)로 분리된다. 그리고 비전도성 산물

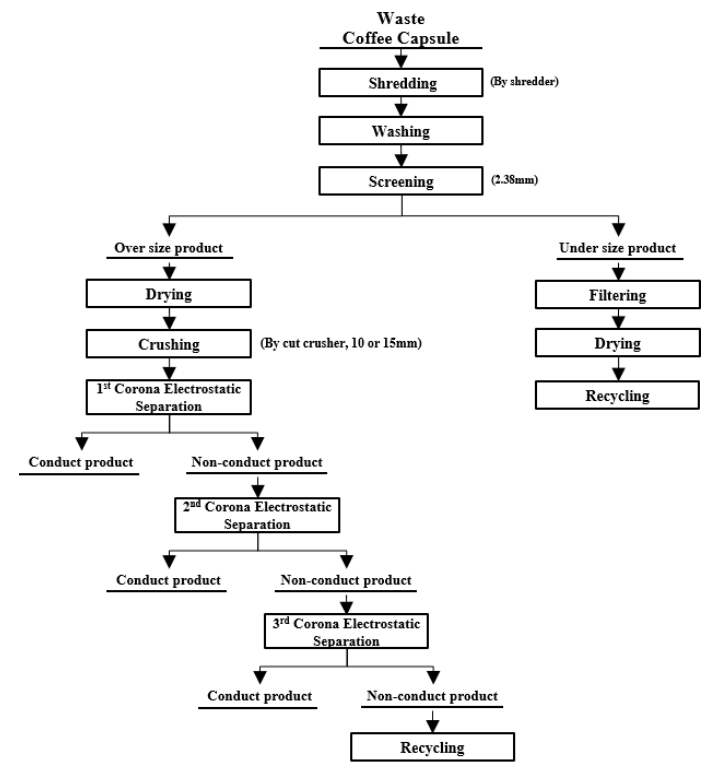

Fig. 12. Material separation process of waste coffee capsules developed in this study.

을 대상으로 알루미늄 제거율 향상을 위한 2 번의 정선 과 정을 거쳐 최종 산물이 얻어지는 공정이다. 이때 $-10 \mathrm{~mm}$ 의 경우, 최종 산물의 알루미늄 제거율과 플라스틱 회수율 이 각각 $95.4 \%$ 와 $98.3 \%$ 이었으며, $-15 \mathrm{~mm}$ 는 각각 $91.3 \%$ 와 $97.2 \%$ 이었다. 앞서 언급했듯이 선별효율은 $-10 \mathrm{~mm}$ 가 $-15 \mathrm{~mm}$ 보다 효율적이지만, 파쇄효율 측면에서는 입도 가 큰 $-15 \mathrm{~mm}$ 가 효율적이다. 따라서 향후 입도는 선별효 율과 파쇄효율을 고려해 선택해야 할 것으로 생각된다.

\section{3. 결 론}

본 연구에서는 현재 생활계 폐기물로 버려지는 커피 캡 슐의 재활용을 위한 재질분리 연구를 수행하였으며, 다음 과 같은 결론을 얻었다.

1. 본 연구에 사용된 시료는 NESCAFE Dolce Gusto 커피 캡슐로, 재질별 무게 비는 커피 $74.63 \%$, 플라스틱 $24.68 \%$ 그리고 알루미늄 $0.67 \%$ 이었다. 커피를 제외한 무게 비 는 플라스틱이 $97.28 \%$ 로 대부분이며, 알루미늄은 $2.72 \%$ 이었다.

2. 1차 파쇄 후, 체질(8 mesh)을 통해 커피찌꺼기는 제거 되었으며, 이때 알루미늄 단체분리도는 $50.8 \%$ 로 재질 
분리를 위한 2차 파쇄가 필요함을 확인하였다. 커피찌꺼 기가 제거 된 1차 파쇄 산물을 대상으로 $10,15,20 \mathrm{~mm}$ 이하로 2차 파쇄를 수행하였으며, 알루미늄 단체분리 도는 각각 $99.2 \%, 97.1 \%, 95.5 \%$ 이었다.

3. $10,15,20 \mathrm{~mm}$ 이하로 2차 파쇄 된 시료를 대상으로 코 로나 방전형 정전선별을 적용하여 플라스틱과 알루미 늄의 재질분리 연구를 수행하였다. 실험결과, $-10 \mathrm{~mm}$ 시료의 경우, 최적조건에서 알루미늄 제거율 및 플라스 틱 회수율이 각각 $95.4 \%$ 와 $98.3 \%$ 이었으며, $-15 \mathrm{~mm}$ 는 각각 $91.3 \%$ 와 $97.2 \%$ 이었다. 선별효율은 $-10 \mathrm{~mm}$ 시료가 $-15 \mathrm{~mm}$ 시료보다 높지만, 파쇄 측면에서는 입 도가 큰 $-15 \mathrm{~mm}$ 가 효율적이다. 따라서 향후 입도는 선 별효율 및 파쇄효율을 고려해서 선택해야 할 것으로 생 각된다. 또한 $-20 \mathrm{~mm}$ 시료의 경우, $-10 \mathrm{~mm}$ 및 -15 $\mathrm{mm}$ 시료와 비교하여 알루미늄 제거율이 $10 \sim 15 \%$ 낮 아 비효율적임을 확인하였다.

4. 재질분리 된 폐플라스틱의 재활용 가능성을 평가하기 위하여, 시료를 펠릿으로 제조하고 물성을 분석하였다. 분석결과, 유해물질은 검출되지 않았으며, Homo-PP 와 유사한 결과를 보였다. 따라서 재생 $\mathrm{PP}$ 로 충분한 기 능성이 존재하여 가전, 건축 등의 일반적인 사출 소재 로 사용이 가능하며, 신재와 혼합사용 시, 등급이 높은 다양한 제품군에 적용 가능할 것으로 평가되었다. 다 만, 어두운 색상으로 인해 검정 혹은 어두운 계열의 제 품군에 한정적으로 적용 가능할 것으로 평가되었다.

5. 본 연구에서는 폐 커피 캡슐의 재활용을 위해 1 차 파쇄, 세척 및 체질을 통해 커피찌꺼기를 제거하고 2차 파쇄 후, 총 3 번의 코로나 방전형 정전선별을 수행하는 재질 분리 공정을 개발하였다. 이때 알루미늄이 약 91 95\% 제거 된 폐플라스틱을 약 97 98\% 회수하였으며, 이렇 게 회수 된 폐플라스틱은 다양한 분야에 적용 가능할 것으로 평가되었다.

\section{감사의 글}

본 연구는 한국지질자원연구원 주요사업인 ‘국내 부존 바나듐(V) 광물자원 선광/제련/활용기술 개발(GP2020013, 21-3212-1)' 과제의 일환으로 수행되었습니다.

\section{References}

1. EUROMAP, 2016 : Plastric Resin Production and Consumption in 63 Countries Worldwide.

2. Korea Ministry of Environment, Waste Generation and Treatment status (2011-2017), http:/www.me.go.kr/home/ web/policy_data/read.do? menuId $=10265 \&$ seq $=7308$, October 19, 2020.

3. Baek, S.H., Jeon, H.S., Kim, S.G., et al., 2013 : Development of Triboelectrostatic Separation Technique for Recovery of Nylon from Radiator of End-of-Life Vehicle, J. of Korean Inst. of Resources Recycling, 22(1), pp.1-7.

4. Lee, S.H., 2019 : Current Status of Plastic Recycling in Korea, J. of Korean Inst. of Resources Recycling, 28(6), pp.3-8.

5. Profshare Market Research, 2018 : Capsule Coffee Machines Market by Product (Closed Source System, Open Source System) by Application (Household, Commercial) by Industry Analysis, Volume, Share, Growth, Challenges, Trends and Forecast 2018-2026.

6. BomFim, A., Maciel, M., Voorwald, H., et al., 2019 : Effect of different degradation types on properties of plastic waste obtained from espresso coffee capsules, Waste Management, 83, pp.123-130

7. Han, S.S., Park, S.S., Kim, S.M., et al., 2014 : Simulation on the PCB Particle Trajectories in Corona-discharge Electrostatic Separator, J. of Korean Inst. of Resources Recycling, 23(6), pp.30-39.

8. Wu, J., Li, J., and Xu, Z.M., 2007 : Optimization of key factors of the electrostatic separation for crushed PCB wastes using roll-type separator, Journal of Hazardous Materials, 154, pp.161-167.

9. Younes, A., Younes, M., and Sayah, H., et al., 2013 : Effect of spark discharges on the trajectories of insulating particles in roll-type corona-electrostatic separators. Experimental and numerical study, Journal of Electrostatics, 71, pp.84-91.

10. Veit, H.M., Diehl, T.R., and Salami, A.P., et al., 2005 : Utilization of magnetic and electrostatic separation in the recycling of printed circuit boards scrap, Waste Management, 25, pp.67-74.

11. Jeon, H.S., Baek, S.H., Park, C.H., et al., 2010 : Development of Electrostatic Separation Technique for Recovery of Soft PVC from Medical Plastic Waste, J. Korean Soc. Miner. Energy Resour. Eng., 27(2), pp.159-164. 


\section{백 상호}

- 과학기술연합대학원대학교 자원순환공학과 공학박사

- 현재 한국지질자원연구원 광물자원연구본부

연구원

\section{한 요 셉}

- 한양대학교 자원환경공학과 공학박사

- 현재 한국지질자원연구원 광물자원연구본부

선임연구원

- 현재 한국과학기술연합대학원대학교

자원순환공학 부교수

- 당 학회지 제 30 권 2 호 참조

\section{김 성 민}

- 한양대학교 자원환경공학과 공학박사

- 현재 한국지질자원연구원 광물자원연구본부

연구원

- 당 학회지 제 29 권 5 호 참조

\section{Tsogchuluun Davaadorj}

- Mongolian University of Science and Technology,

Mining Technology Engineering, Bachelor

- 현재 과학기술연합대학원대학교 자원순환공학과 박사과정

\section{전호 석}

- 강원대학교 자원공학과 공학박사

- 현재 한국지질자원연구원 광물자원연구본부

책임연구원, 자원회수연구센터 센터장

- 현재 한국과학기술연합대학원대학교

자원순환공학 교수

- 당 학회지 제 29 권 5 호 참조 